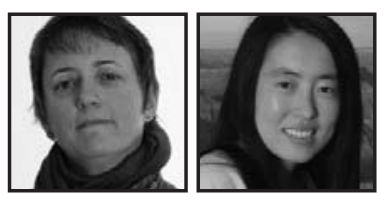

\title{
Unexpected Learning: Two PhD Candidates Narratively Inquire Into Their Experiences With an ESL Group
}

Sandra Jack-Malik \& Miao Sun, University of Alberta

\section{ABSTRACT}

We inquired into stories we lived whilst members of an ESL group. We used a narrative inquiry methodology. Our inquiry revealed tensions between identities given and identities continually negotiated between teacher, student and group member. Dewey's (1938) concept of experience, notions of literacy acquisition (Collins \& Blot, 2003; Cummins, 2001; Heath, 1983; Rose, 1989; Street, 1995), and Connelly and Clandinin's (1990) ideas about teacher knowing, teacher identity and curriculum serve as the theoretical framework. Our inquiry helped us imagine educational landscapes which are responsive to ESL learners and a place where members of dominant discourse communities can wonder about the existence of hegemony.

\section{1}

chose a course-based Masters. I made this decision because I assumed Canadian and Chinese scholars conducted research differently. I was confident of my ability to be successful with course work, as I had always been in China. The differences in research methods concerned me, so I decided to avoid the issue by taking the course-based route. My confidence was soon interrupted as I encountered huge differences between what I expected and what I faced. I tried my best to adjust to the Canadian way of doing things, not just with my courses, but with everything. I felt it was my responsibility to change. I was the newcomer; therefore, I believed I had no right to ask people to make changes for me. Moreover, it was my repeated experience that people were not interested in my ways of knowing and being." (Miao Sun, in conversation with Sandra Jack-Malik, 2009) 


\section{Introduction}

We hear Miao say she arrived in Canada confident of her ability to successfully engage in and complete a course-based Masters; however, this confidence was quickly interrupted when she repeatedly encountered situations where her way of knowing and being did not garner acceptance or result in a successful outcome. Moreover, we understand Miao believed it was her responsibility to make the required changes which would allow her to successfully "fit" in.

We began our doctoral studies in the fall of 2007. By December of the first year we were involved in a weekly ESL group. We came to the group for different reasons. Miao, as noted in the above snippet of conversation, was hoping to acquire native-like fluency and in so doing move away from the tensions and take a step towards acceptance within the academic community. Miao's coming to the group, therefore, was part of her strategy to develop the skills which would allow her to fit in. Sandra, who was also experiencing tensions, was hoping for a quick and safe return to the position of teacher and expert because she was struggling with a torrent of change which sometimes results when an experienced teacher returns to the academy and assumes a student identity. Moreover, Sandra believed she had the knowledge and skills which she could dispense to Miao and thus help her to fit in. In this paper, using a narrative inquiry methodology and narrative constructions of identity and identity shifts, we inquire into our involvement with the (ESL) group. We framed our autobiographical inquiry into our experiences with the ESL group as a journey and as a conversation because we see it as a series of linked, relational experiences, which over time afforded us the opportunity to shift our identities by telling and retelling our stories to live by ${ }^{1}$ as teacher, student and as members of discursive communities. This paper includes both our perspectives and it is written as a series of dialogical stories, followed by an inquiry into these stories. Our aim was to deepen our understanding of the lived curriculum ${ }^{2}$ as we experienced it within our ESL group and to understand the possibilities it afforded us for identity shifts.

\section{Framing Our Study}

Drawing on the following epistemological and theoretical ideas, we framed our narrative inquiry into our experiences of participating in the ESL group. We began with Dewey's notion of experience (1938) to provide a foundation upon which our thinking rested. Then we considered notions of literacy acquisition (Collins \& Blot, 
2003; Cummins, 2001; Heath, 1983; Rose, 1989; Street, 1995) which afforded us the opportunity to consider the links between literacy acquisition, power and identity. Moreover, we leaned on the work of Clandinin and Connelly (1995) for ideas about teacher knowing, teacher identity and curriculum.

\section{Experience and Identity}

As we began to inquire into our stories we had many wonders. We understood we are both doctoral students within the same faculty; however, because of our life experiences we had positioned ourselves differently in relation to one another and with respect to our place within the academy. We wondered about our individual positioning and in particular we wondered what had and was influencing it. With this in mind, we turned to Dewey's (1938) notion of experience which allowed us to appreciate

every experience enacted and undergone modifies the one who acts and undergoes, while this modification affects, whether we wish it or not, the quality of subsequent experiences, [such that] the continuity of experience means that every experience both takes up something from those which have gone before and modifies in some way the quality of those which come after. (p. 35)

With Dewey's theory of experience in mind we then considered Macintyre's (1998) and Bruner's (1991) argument that humans are narrative beings telling who they are through story. Moreover, they posited identity is constrained by one's place in society and by the interconnectedness of the events and experiences as we meaningfully thread them together. This thought allowed us to wonder about the hegemony embedded in Sandra's decision to set up the ESL group and about Miao's feelings that she was solely responsible for making what she perceived as the required changes which would result in her fitting in. We also considered Carr's (1986) and Crites' (1979) narrative coherence such that, we struggle to make sense through the stories we tell across time and context. Moreover, because we were researching our involvement in the group over an extended period of time and because we believed we had both experienced identity shifts, we thought about Connelly and Clandinin (1999) who view identity as embodied, fluid and multiple, depending upon context. Finally, we understood our experiences in the ESL group had generated a new relationship between ourselves and the discursive communities in which we engaged. In 
constructing our descriptions and explanations of our experiences with the ESL group, we wanted to account for the identity shifts which had allowed us to "generate a new relation between a human being and her environment - her life, community, world" (Clandinin \& Rosiek, 2007, p. 39). According to Dewey (1981) this new relation will be "... more significant, and less overpowering and oppressive" (p. 175); this is what we imagined in our future stories.

\section{Literacy Acquisition, Power and Identity}

Sandra created the ESL group believing she had skills and knowledge to dispense; she supposed said skills were required by her international colleagues. Miao came to the group because she saw it as part of her strategy to acquire the skills which would allow her to fit in. These were our intentions at the outset; however, over time we both realized there was much more going on and we wanted to understand it. We began by reading in the area of subsequent language acquisition which views language learning as a process embedded in a number of sociocultural contexts (Toohey, 2000). Collins and Blot (2003) and Street (1995) described reading and writing as processes embedded with values, attitudes and beliefs. Heath (1983) described literacy learning as a process which included and privileged some while excluding others. Bucholtz and Hall (2003) described this exclusion as markedness or the "hierarchical structuring of difference" (p. 3). This markedness is problematic, they argue, when the unmarked group is assumed as the norm and its right to power is taken for granted and therefore difficult to challenge. Those whose identities are marked as not possessing the "norm" may struggle within hegemonic discourses as they attempt to meet the unmarked norm. Cummins (2001) described a process where language learning ought to be viewed through a lens of what he called, "identity negotiation."

\section{Teacher Knowing and Teacher Identity}

As we shared our stories it quickly became apparent to us that Sandra had shifted her identity away from expert teacher / knowledge dispenser. What originally began as well-planned, detailed lessons had morphed into otherwise and we were curious to understand why this had happened. Connelly and Clandinin $(1988,1999)$ described teachers as knowledge possessors or knowers. They coined the phrase "personal practical knowledge" to describe teachers as holders of knowledge: 
Personal practical knowledge is past experience, in the person's present mind and body, and in the future plans and actions. Personal practical knowledge is found in a person's practice. It is, for any one person, a particular way of reconstructing the past the intentions of the future to deal with the exigencies of a present future. $(1988$, p. 25$)$

With teachers as knowers, Connelly and Clandinin's (1988) view of curriculum is as "something experienced in situations." They saw situation as "made up of people and their surrounding environment" (p.6). Curriculum then is experienced by teachers in dynamic relationships with students whilst living out previously composed stories and directing thought to future stories. Therefore, they argued if a teacher understands her personal practical knowledge, she is better able to understand the curriculum making she is engaged in.

Connelly and Clandinin turned to the work of Carr (1986) in their efforts to connect teacher experiences and teacher identity. Carr spoke about narrative coherence such that "the narrative coherence of a life-story is a struggle" (p. 96). Connelly and Clandinin used the term "stories to live by" to narratively conceptualize teacher identity which includes personal practical knowledge and identity. Reading this work encouraged us to wonder what had happened and continued to happen in our weekly meetings which had supported our shifts in identity.

\section{Our Method}

We wanted a way to inquire into the stories we were sharing, therefore we turned our exploration to what Clandinin and Connelly (2000) described as a metaphorical three-dimensional narrative inquiry space. This metaphorical space has the notion of temporality along one side (Dewey's continuity), personal and social along a second side (Dewey's interaction) and place along the third (Dewey's situation). Clandinin and Connelly (1994) added to this description by including what they termed the four directions of inquiry: inward and outward and back and forward. They used the word "inward" to focus attention on the internal conditions of those involved with the inquiry; hopes, feelings, aesthetic reactions and moral dispositions were things to be inquired into. By using the word outward the authors were referring to the existential conditions: the environment. Clandinin and Connelly (2000) described the inquiry process as follows: "to experience an experience - that is, to do research into an experience - is to experience it simultaneously in these four ways 
and to ask questions pointing each way" (p. 50). Leaning on this three-dimensional space which is grounded in Dewey's theory of experience, we continued our explorations.

We begin with the story which was the catalyst for the formation of our group.

\section{Sandra: How the ESL group began}

I am a participant in a weekly gathering (research issues) of students and academics at the Centre for Research for Teacher Education and Development at the University of Alberta. D.J. Clandinin is the director of the centre and she is also my supervisor. Participating in these meetings, I came to appreciate what Steeves et al. (2009) described when they wrote about their experiences having attended research issues:" participants come to know the necessity of creating a safe and caring tone for sharing work and experiences in their lives, for inquiring and voicing concerns related to issues of research and teacher education" (p. 308). I was, however, reluctant to attend the meetings. Dr. Clandinin began inviting me to participate early in 2008; however I did not feel I had anything to contribute. After several invitations I tentatively began attending. One day I was seated next to a colleague who had chosen to share some of her writing. As the woman read I was moved by the originality of the sentence structure and by the depth of my emotional reaction to the writing. When she finished reading I expected the group to offer response as was the custom; this did not happen. I did not understand and I was too shy to offer my own response. I wondered if perhaps those in attendance had experienced difficulty in understanding what had been read; English was not the woman's first language. I realized I had been reading along because the pages were on the table in front of us and therefore, I had understood everything. Later that evening as I reflected on the meeting, I thought I would like to offer my expertise (Master's Degree in ESL) to the woman. Tentative e-mails were exchanged, lesson plans were written which included lists of target skills (correct phoneme production, vocabulary development, voice projection, stress, tone and intonation, etcetera) and so began the weekly ESL group. After a month, two more members joined the group, a visiting scholar and Miao.

\section{Sandra inquires into the beginning story}

Because of the experiences I was having at the weekly research issues meetings, I felt I could and wanted to help. Today, when I inquire into my decision to offer assistance, I believe it was grounded in my desire to stand on familiar, nonjudgmental 
ground. Moreover, I believe it was grounded in the university counterstory ${ }^{3}$ experiences I was having at research issues where relationship and respect were consistently foregrounded. Many things about being a doctoral student were otherwise; at each turn, what I thought, wrote and said was judged. I worked as a teacher for eighteen years; I had reached a place where I felt a certain degree of confidence in my work. When I began my studies this instantly changed because I was a student, studying within a system where judgment and competition were central to the process. I now believe, therefore, that part of the reason I offered to help was related to a familiar embodied story, part of my personal practical knowledge ${ }^{4}$ that I was experiencing. I wanted to return to the comfort of teacher and expert in an effort to interrupt the constant judgment. I chose to design a new in-classroom space, one where I would position myself in a way that let me live out my personal practical knowledge. When I prepared the skills checklists and the lesson plans, I was comforted not only by the familiarity of the routine but also by my anticipated return to the front of the class. This was part of my stories to live by, my identity, who I knew myself to be in my teaching practice and how I understood the meaning of literacy.

Thinking about the personal and social side (Dewey's interaction) of the three-dimensional narrative inquiry space, I acknowledge that when I began my behaviour was grounded in hegemonic thinking in that it did not occur to me that my involvement would quickly become as much about who I am and how I position myself in the world as it was for Miao. When I began, I saw myself as teacher; dispensing knowledge from the front of the class and in so doing I would experience the comfort of familiarity.

\section{Miao's first story: A classroom spectator}

It was the fall of 2003, my first term in Canada as an international student and I was studying for a second master's degree. I was sitting in a classroom of approximately ten students. Two thirds of the class time had passed and I had not said a word. My classmates were actively discussing something with our professor. A student was talking and several others were raising their fingers or pens, indicating they would like to share something. I watched and listened; my eyes constantly switching from one person to another as the speaker changed. People were speaking so hurriedly and the topics continually shifted; I had no clue how and where to fit my ideas into the conversation. Sometimes I nodded when the others nodded and laughed when the others laughed although I did not really understand why. 


\section{Miao inquires into this story}

My early experiences as an international student in Canadian classrooms were so frustrating that I often lacked confidence and therefore did not frequently participate. I most often behaved as a spectator rather than an active participant, unless I was invited into a discussion by a professor or a classmate. Even after I was accepted into a doctoral program in 2007 , my reluctance to participate lingered. I believed that in the eyes of my classmates, I was a quiet, Asian girl, with no personal opinions to contribute to discussions. When I began the course work for my PhD I continued to pretend to understand and often I pretended to laugh. I read Crites' (1979) broadened notion of coherence which included self-deception and the cover stories humans sometimes tell in efforts to make the narratively constructed story appear more acceptable. I now understand my pretending and laughing were cover stories created and enacted in my efforts to be included. Moreover, I understand my classmates pretending to understand me as their contribution to the cover story. This pretention allowed them to avoid having to take the necessary time to clarify when communication barriers arose which I perceived to be the result of my English pronunciation. They joined me, it seemed, in co-composing shared cover stories.

When Sandra invited me to the ESL group I was delighted to have the chance to learn correct English pronunciation from a native speaker. Crites (1979) described forward-looking stories. I wanted to improve my English, I wanted to participate in class discussions; these were my forward-looking stories to live by. I expected Sandra to tutor me in my pronunciation and tell me exactly what to do in order to improve my productive communication skills. When I envisioned my participation in the ESL group, I imagined I would listen and imitate what Sandra, the expert native speaker, asked of me. This was a comfortable and embodied story, a habitus (Kerby, 1991) one I had lived for many years as a student in China. Also, I hoped that at long last I would acquire native-like pronunciation and fluency: two skills which are highly regarded in China. Furthermore, I believed having these skills would allow me to fit in while garnering immediate acceptance from the Canadian academic community.

Considering Dewey's notion of temporality, I now understand my imagined behaviour and my identity as a student as linked to my cultural and educational background as a highly successful student within the Chinese system. A system where the teacher is expert and the student's job is to receive the knowledge being transmitted by the teacher; I was skilled in this method. Moreover, I think it is important to note that when I was a child I would not have directly asked the teacher a question because it might have been interpreted as a sign of disrespect and a challenge to the 
teacher's authority. There were very clear expectations of what constituted appropriate student and teacher behaviour. Teachers were considered exceptional if they had limitless subject knowledge which they daily poured into the minds of their expectant students. Pupils were marked for success by hard work, outstanding grades and unequivocal respect for the teacher. Being a student in Canada, I experienced tensions therefore, between the identity, the stories I lived by when I arrived in Canada and the stories I was expected to live out (Carr, 1986) and that were required for success on a Canadian academic landscape. These tensions continually bumped up against (Clandinin et al., 2006) the stories I was composing, such that I was regularly asking myself who I was, who I wanted to be and who I needed to be. Coffee and Street (2008) "argued that learners own retrospective accounts of their learning draw on a range of discursive identities [which in turn] allows more nuanced glimpses into how individuals narrativise language learning as an identity project" (p. 452).

\section{Sandra's second story: The first hint of an identity shift}

I was delighted when Miao joined our group. At the time we were in a class together. One of the assignments involved individuals or small groups presenting a forty-minute seminar on the work of a pivotal thinker, in the area of literacy. It was the first time I heard Miao speak; she completely captured my attention. I realized how very clever Miao is and I felt myself listening differently from that moment forward. Later we were together in a second class and I was impressed by the professor's repeated invitations to engage Miao in class discussions as a valued member of the group. Miao always had interesting things to offer which allowed me to think about an issue from a different perspective; however, she only shared her thinking when invited to do so.

\section{Sandra inquires into this story}

Today when I think about my relationship with Miao, I understand I had a homogenized notion of her (King, 2003) because of her non-native sounding speech patterns. I had, as Bucholtz and Hall (2003) argued, marked her as less than the norm because of her non-native speech production. I now realize this notion was grounded in hegemonic thinking. I acknowledge that my homogenized, less-than labelling of Miao prevented the uniqueness of her identity from penetrating the label (Khayatt, 2001). Understanding this allowed me to wonder how I was manipulating the stories of other students I met, who did not speak with native-like fluency to fit within the homogenized, less-than label. I was wondering about this while meeting each week for an hour and a half with international students and visiting scholars. Slowly and 
over time as members shared their stories to live by, I was afforded the opportunity to understand individual and sometimes shared stories of life within and upon an ESL landscape. ${ }^{5}$ This in turn led to a broader range of possibilities, some which were resistant to and some which were complicit with my homogenized labelling of students for whom English was not their first language (King, 2003). I was glad for the realization because understanding this tendency and recognizing it allowed me to experience it as a tension when listening to the stories being told. When this happened I actively opened myself to hearing the story and experiencing the tension which was most useful in that I was able to see my own experiences reflected in the stories I heard. This shared experience drew me inward and allowed me to experience what Clandinin and Connelly (2000) described as hopes, feelings, aesthetic reactions and moral dispositions of myself and of others. In the midst of this I felt a tiny slip from my pedestal of teacher, and a move towards an alongside relationship (Clandinin \& Connelly, 2000).

Lugones (1987) described a process of world travelling to someone else's lived experiences with loving compassion. Each week as I inquired further into the stories we were sharing, I felt a non-judgmental space opening up within myself, which in turn allowed easier travel to the worlds of otherwise described by group members. Moreover, the inquiry into the stories has facilitated moments of what Hoffman (1994) referred to as resonant remembering because the stories shared drew forward some of my own memories, which had been dormant. This resonant remembering facilitated another shift in my teacher identity as once again I experienced coming alongside as a member of the group and not as the expert teacher because I saw myself, my struggles for narrative coherence (Carr, 1986), reflected in the stories being shared. I also understood that there are occasions when a student's personal practical knowledge coupled with the uniqueness of a particular context and our place within it (Maclntyre, 1998) can act as a limit upon participation. As the teacher I could behave in ways which invited participation and perhaps mitigated some of my students' reluctance to participate, while also shifting me away from the limits of labelling.

\section{Miao's second story: How will I learn if the teacher speaks less?}

I was a little surprised when Sandra told us she had listened to the digital recording of our class and concluded she was speaking too much and she wanted to reduce the number of minutes she spent speaking. I considered Sandra the teacher and role model in our group and I assumed she was the person who should be doing most of the speaking. I wondered, therefore, how I would learn from Sandra if she spoke less. 


\section{Miao inquires into this story}

I appreciate my expectation for Sandra to do most if not all of the speaking is a result of my early stories to live by when I was a knowledge receiver who was expected to say very little. I now understand that within this cultural narrative, my personal practical knowledge was, and to a certain extent, continues to be embedded. I also understood that myself, as a student spectator, had become what Kerby (1991) described as habitus. I began to realize I was appreciating the opportunity Sandra's reduced talking provided for me and the group members. As I was encouraged to speak more, for the first time I felt I was a contributing member of the group. It made me feel I owned my place and my opinion was valued and sought out. As the weeks passed and my active participation in our ESL group increased, I realized my identity as a student was shifting from that of a spectator to that of an active, contributing participant in both the ESL group and in my regular classes.

Over time my participation in the ESL group brought me feelings of belonging and accomplishment within the Canadian educational landscape. As Bateson (1994) argued, education is not a preparation for participation; rather, in Dewey's (1916) words, "education is participation." I had felt frustrated when I identified and was identified by others as a quiet, passive, and sometimes marginalized spectator in a classroom. I was more able and willing to actively participate in the ESL group because within this landscape we created an environment where we belonged based on our willingness to share, respond to and reflect upon our stories to live by. Within this space I felt emboldened to begin a process of identifying as a participant learner while rethinking my identity as a knowledge receiver (Belenky, 1986).

\section{Sandra: Another look at the tape recorder story}

One Friday morning I asked the group if I might digitally record the session in efforts to reflect on my teaching practice. When I got the recording home and downloaded it to my computer, I was stunned to realize how many of the ninety minutes I spent talking. I decided I wanted to speak less and hopefully create more space for the students to speak, to practice. In my weekly meeting with my supervisor I explained my plan of action. I felt very good and rather clever about my decision. Dr. Clandinin responded by suggesting that I think about who I was in the group. She spoke about standing in front of a class and about being a member of a community; she wondered how I perceived my participation in the ESL group. Dr. Clandinin's response had not been what I wanted or anticipated, however, it did encourage me to consider my stories to live by as teacher and I realized I was still clinging to the pedestal which I had moved closer to the group; nevertheless I was still not a member 
of the group. I now believe this to have been the case because my teacher stories did not include a vision of myself as a member of a group. Moreover, my story was a cover story (Crites, 1979) told and retold to avoid genuine group membership which required a commitment to intimacy of relationship, something for which I was not ready. Remaining upon my teacher pedestal and shrouded within the comfort of my familiar teacher story kept intimacy at arm's length. While I was having experiences which served as interruptions to this story, I was reluctant to engage in what Vinz (1997) described as "dispositioning," such that I would create spaces where I might "rethink and reconceptualize what it means to educate and to be educated" (p. 138). I began to wonder how I could story my teaching and learning in ways which did not reinforce my place on the teacher pedestal. I began to consider forward-looking stories (Lindemann Nelson, 1995) of teaching and learning and I envisioned myself within a group; and I was hopeful. hooks (2003) wrote "I work to recover our collective awareness of the spirit of community that is always present when we are truly teaching and learning" (p.xv).

\section{Miao's third story---Stop me if you don't understand}

In one of the ESL group meetings in the second year, Sandra suggested we try something new. She invited each of us to share a story from our recent winter vacation. She asked we do this first in pairs and then our partner would stand up and summarize our story. When someone was speaking, Sandra asked the listeners to raise their hands, signalling to the speaker that a member of the group did not understand what had been said. We had a great time with this activity. We were laughing together and joking around with our hands up and down when there was a misunderstanding caused by pronunciation or expression errors. Sandra kept encouraging us to help each other in clarifying meaning and offered her help only when necessary.

\section{Miao inquires into this story}

In retrospect, I was amazed by how calm and comfortable I was when fellow students raised their hands to stop me when communication barriers occurred. I could not have imagined this happening when I first arrived in Canada because I often acted as a spectator and felt so hesitant to participate because of my lack of communicative confidence. I wonder if I was not relieved that my classmates did not stop me for clarification when they did not understand. If they had, I suspect I would have reacted by becoming more frustrated and, in turn, quieter. I began to wonder how the landscape of the ESL group made such a difference in my learning experiences. 
I realized that the ESL group not only provided a belonging place for my participation, but also a safe and inclusive space for my playful engagement. As Steeves (2006) states, "If as Dewey (1938) believed, education is a social process and participation holds the key for continual learning, then intentionally creating safe reflective spaces in educational institutions for inclusive participation is a necessity" (p. 107). The ESL group created a space where I felt safe and I knew I belonged, which in turn supported my increased willingness to participate. As Clandinin and Connelly (1995) stated, it is a "secret place" that provides a relationship space that is more favourable for learning and growing. Compared with the formal classroom settings, this secret place was more responsive to an international student like me. I wonder if the academy could provide more secret places such as the ESL group, in which we could create our own secret stories instead of trying to fit within standardized academy stories.

\section{Conclusion}

As Coles (1989) stated, "their story, yours, mine---it's what we all carry with us on this trip we take, and we owe it to each other to respect our stories and learn from them" (p. 30). Our stories to live by, our identities as teacher, student and members of the ESL group reveal the tensions between the identities we brought to the group and the identities we continually negotiated in and through relationships. Through the story-telling we realized not only were our individual stories to live by (our identities) shifting, but also our perspectives on each other were shifting.

Although we came to the ESL group for different reasons, through our inquiry into our stories we learned to think differently and in so doing, shifted our identities. Miao began to explore other possible stories as an international student within the Canadian academy and she began to question her previous belief that it was her sole responsibility to make the changes which would allow her to experience feelings of fitting in. Sandra, on the other hand, began to question the contribution she was making to the hegemonic doctoral student environment, her homogenized notions of international students and her position as expert teacher and knowledge dispenser. Our inquiry into our stories therefore allowed us to consider other possibilities and to "move out of the lived story to tell with another 'I', another kind of story" (Clandinin \& Connelly, 1991, p. 141). 
Willis (1997, p. 388) reminds us that, "There is no singular history of literacy, nor is there a singular definition of literacy for there have been multiple definitions of literacy, multiple histories of literacy, and multiple paths to literacy" (Graff, 1995). Our ESL group is a secret place where we create our own literacy stories as knowledge holders, teachers, learners and as members of community. The constant identity negotiation in our ESL group helped us gradually develop a safe and comfortable language and literacy acquisition environment for the teacher and for learners from diverse cultural backgrounds. The alongside, relational commitment between group members reveals literacy acquisition is embedded in and reflects the social and cultural contexts. The lived curriculum we experienced in this ESL group provides insights for how better to support international ESL students in academic communities while also highlighting the hegemonic beliefs carried by members of the dominant discourse communities.

When we return to Miao's original story from her early days in Canada, we wonder how her experiences might have been different if she had had a secret place where she could have shared her lived stories and inquired into them. Moreover, we wonder what it would be like for international students, professors and instructors if they each began at the point at which we are presently. Can we learn to think about international students differently? Can the ESL markedness be something we value? It has come to mean precisely that for Sandra because she understands and appreciates that the shifts she made and continues to make were possible because of her involvement with the ESL group.

\section{Notes}

1. Connelly and Clandinin $(1988,1999)$ described the storied lives lived and told by teachers as a conceptual framework for narratively understanding the links between what teachers know, the various contexts in which they live and their identities.

2. Connelly and Clandinin (1988) described curriculum as "something experienced in situations" and they described situations as being "made up of people and their surrounding environment" (p. 6.).

3. Clandinin et al. (2006) defined counterstories as"narratives composed to shift the taken-for-granted institutional narrative" (p. 171). 
4. Clandinin and Connelly (1995) described personal practical knowledge as "that body of convictions and meanings, conscious or unconscious that have arisen from experience (intimate, social, and traditional) and that are expressed in a person's practices."

5. Clandinin and Connelly (1995) used a landscape metaphor to describe as the places where we live, work and play and as storied places where lives are composed, lived and relived.

\section{References}

Bateson, M. (1994). Peripheral visions: Learning along the way. New York: HarperCollins.

Belenky, M. (1986). Women's ways of knowing: The development of self, voice, and mind. New York: Basic Books.

Bruner, J. (1991). Self making and world making. Journal of Aesthetic Education, 25, 67-78.

Bucholtz, M., \& Hall, K. (2003). Language and identity. In A. Duranti (Ed.), Companion to linguistic anthropology. Malden, MA: Blackwell.

Carr, D. (1986). The self and the coherence of life. In Time, narrative and history, (73-99). Bloomington: Indiana University Press.

Clandinin, D.J., \& Connelly, F. M. (1991). Narrative and story in practice and research. In D. Schon (Ed.), The reflective turn: Case studies in and on educational practice. New York: Teachers College Press.

Clandinin, D.J., \& Connelly, F. M. (1994). Personal Experience Methods, in Denzin, N.K. and Lincoln, Y. S. (Eds) Handbook of Qualitative Research, SAGE Publications, 413-427.

Clandinin, D.J., \& Connelly, M. (1995). Teachers' professional knowledge landscape. New York: Teachers College Press.

Clandinin. D.J., \& Connelly, M. (2000). Narrative inquiry: Experience and story in qualitative research.: San Francisco: Jossey-Bass

Clandinin, D.J., Huber, J., Huber, M., Murphy, M.S., Murray-Orr, A., Pearce, M., \& Steeves, P.
(2006). Composing diverse identities: Narrative inquiries into the interwoven lives of children and teachers. New York: Routledge.

Clandinin, D.J., \& Rosiek, J. (2007). Mapping a landscape of narrative inquiry: Borderland spaces and tensions. In D. J. Clandinin (Ed.), Handbook of narrative inquiry: Mapping a methodology, (35-76). Thousand Oaks, CA: Sage Publications.

Coffee, S., \& Street, B. (2008). Narrative and identity in the "language learning project" The Modern Languages Journal, 92(3), 452-464.

Coles, R. (1989). The call of stories: Teaching and the moral imagination. Boston: Houghton Mifflin Company.

Collins, J., \& Blot, R. (2003). Literacy and literacies: Text, power and identity. Cambridge: Cambridge University Press. Houghton Mifflin.

Connelly, F.M., \& Clandinin, D.J. (1988). Teachers as curriculum planners: Narratives of experience. New York: Teachers College Press.

Connelly, F.M., \& Clandinin, D.J. (1990). Stories of experience and narrative inquiry. Educational Researcher, 19(5), 2-14.

Connelly, F.M., \& Clandinin, D.J. (1999). Shaping a professional identity: Stories of educational practice. New York: Teachers College Press 
Crites, S. (1979). The aesthetics of self deception. Soundings, 62, 107-129.

Cummins, J. (2001). Negotiating identities: education for empowerment in a diverse society. California: California Association for Bilingual Education.

Dewey, J. (1916). Democracy and education. New York: Macmillan.

Dewey, J. (1938). Experience and education, New York: Macmillan Publishing Company.

Dewey, J. (1981). The later works, 1925-1953: Vol. 4. The quest for certainty: A study of the relation of knowledge and action. J.A. Boydston (Ed). Carbonadale: Southern Illinois University Press.

Heath, S. B. (1983). Ways with words: Language, life and work in communities and classrooms. Cambridge: Cambridge University Press.

Hoffman. E. (1994). Let memory speak. New York Times Book Review.

hooks, b. (2003). Teaching community. New York: Routledge.

King, T. (2003). The truth about stories: A native narrative. Toronto: House of Anansi Press.

Kerby, A.P. (1991).Time and memory. In Narrative and the self (15-31). Bloomington: Indiana University Press.

Khayatt, D. (2001). Revealing moments: The voice of one who lives with labels. In C.E. James \& A.L. Shadd (Eds.), Talking about identity encounters in race, ethnicity and language (74-88). Between the Lines: Toronto, Ontario.

Lindemann Nelson, H. (1995). Resistence and insubordination. Hypatia, 10(2), 23-43.
Lugones, M. (1987). Playfulness, "world"-traveling, and loving perception. Hypatia, 2(2), 3-19.

Maclntyre, A. (1998). A short history of ethics: A history of moral philosophy from the Homeric age to the twentieth century. London: Routledge.

Rose, M. (1989). Lives on the boundary: The struggles and achievements of America's underprepared. The Free Press: New York.

Steeves, P., Yeom, J., Pushor, D., Nelson, C., Mwerabi, B., Murphy, M., Murray Orr, A., Glanfield, F., Huber, J., \& Clandinin, D.J. (2009). The research issues table: A place of possibilities for the education of teacher educators. In C.J. Craig \& L.F. Deretchen (Eds.) Teacher Learning in smallGroup Settings: Teacher Education Yearbook XV11 (303-320). Rowman \& Littlefield: Lanham, Maryland.

Steeves, P. (2006). Sliding doors: Opening our world. Equity \& Excellence in Education, 39: 105-114.

Street, B.V. (1995). Social literacies: Critical approaches to literacy development, ethnography and education. London: Longman.

Toohey, K. (2000). Learning English at school: Identity, social relations and classroom practice. Great Britain: Cambrian Publishers.

Vinz, R. (1997). Capturing a moving form: Becoming as teachers. English Education, 29(2), 137-146.

Willis, A. (1997). Focus on research: Historical considerations. Language Arts, 74(5), 387-397. 


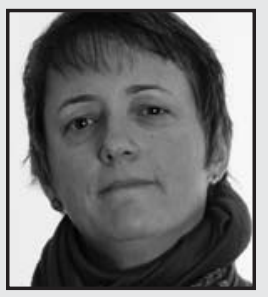

Sandra Jack-Malik is a PhD student at the University of Alberta within the Faculty of Elementary Education. She is also the owner of the Wingate Literacy Clinic where she works as a literacy tutor. Prior to opening the clinic she worked in both the independent and public school systems as a teacher librarian, language arts instructor and as a computer teacher.

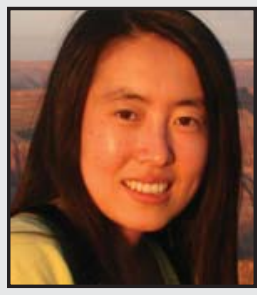

Miao Sun came to Canada as an international student in 2003. She achieved her MA degree in Applied Linguistics at York University in 2005. She is currently a second-year doctoral student in the Department of Elementary Education, Faculty of Education, at the University of Alberta. She is majoring in Language and Literacy Education. 